\title{
PEDAGOGIKA OGÓLNA JAKO WPROWADZENIE DO HUMANISTYKI - HERMENEUTYKA KAPITAŁU SYMBOLICZNEGO I ODZYSKIWANIE CIEMNYCH ISKIER TRADYCJI
}

\begin{abstract}
Streszczenie: Pedagogika ogólna jako miejsce formułowania podstawowej myśli pedagogicznej nie stanowi zamkniętego pola o określonej tematyce, ale punkt widzenia określający to, co istotne we wszystkich subdyscyplinach pedagogiki oraz w praktyce wychowawczej. Zadaniem tak pomyślanej pedagogiki ogólnej jest wprowadzanie całej dziedziny w newralgiczne debaty humanistyki - dostarczanie kontekstów do nieustannego (re)definiowania tego, co pedagogiczne. A ponieważ humanistyka to w dużej mierze hermeneutyczna „praca w tradycji”, pedagogika ogólna jawi się jako perspektywa troski o tradycje pedagogiki. Niniejszy tekst tak właśnie lokuje pedagogikę ogólną, starając się jednocześnie odpowiedzieć na pytanie, czym jest, a czym nie jest produktywna troska o tradycję.
\end{abstract}

Słowa kluczowe: pedagogika ogólna, historia wychowania, humanistyka, tradycja, hermeneutyka, ciemne iskry.

\section{Pedagogika ogólna jako perspektywa (wprowadzenie)}

Nie uważam, aby zasada społecznego podziału pracy akademickiej, szatkująca rzeczywistość na poletka badawcze zarezerwowane dla specjalistów, była owocna w kulturowej przestrzeni znaczeń odnoszących się do splątanego ludzkiego doświadczenia. Dlatego traktuję pedagogikę ogólną nie jako subdyscyplinę z wyznaczonym (wykrojonym) obszarem tematycznym i metodologicznym, lecz jako perspektywę oglądu - spojrzenie na wszystkie kwestie pedagogiczne (szerzej: kulturowe) z pewnego punktu widzenia. Tym samym zakładam, że nie jest to domena ekspertów, usiłujących powiedzieć wszystko, co jest możliwe na temat zakreślonego przedmiotu i tym samym „domykających” stan wiedzy, lecz pole pracy dla intelektualistów, którzy interpretacyjnie „otwierają” myślenie i wyobraźnię pod pewnym kątem (por. Markowski 2013, s. 26-27). 
O jaki „kąt”, o jaki „punkt widzenia” chodzi? Podzielam - choć nie bez zastrzeżeń - stanowisko Zygmunta Mysłakowskiego, który ujmuje pedagogikę ogólną jako syntetyczny opis zjawisk wychowania w ich podstawowej strukturze. I chociaż autor tę ogólną teorię wychowania ujmuje językowo statycznie jako „część” pedagogiki, oraz - jak się wydaje - nie bez intencji metafizycznej abstrahowania od „miejsca i czasu”, gdy ja wolałbym dynamiczne i hermeneutyczne ujęcie historycznie usytuowanego point of view, zasadnicza jego myśl jest czytelna i istotna: chodzi o poszukiwanie tego, co w kulturowych praktykach pozwala nam mówić jednak przy odmienności poszczególnych form - o wychowaniu i co na płaszczyźnie teoretycznej prześwieca konstrukcyjnie przez szczegółowe zagadnienia pedagogiczne; chodzi także o selekcjonowanie tego, co ze względu na tę podstawową strukturę jest znaczące bardziej, a co mniej, i wykrywanie funkcji, jaką pełni wychowanie w całokształcie życia społecznego (por. Mysłakowski 1965, s. 15-16).

Niemiecki teoretyk, Dietrich Benner, stoi na podobnym stanowisku, gdy mówi, że pedagogika ogólna powołana jest do formułowania podstawowej myśli pedagogicznej, czyli takiej, która jest istotna we wszystkich obszarach pedagogicznej praxis (por. Benner 2015, s. 11). Gdy dodaje jednak warunek mówiący o tym, że ogólność tej myśli polega także na zdobyciu przez nią uznania we wszystkich subdyscyplinach naukowej wiedzy o wychowaniu, trzeba zaprotestować i wprowadzić do tej teorii korektę. Uznanie jest to pojęcie z zakresu społecznych stosunków władzy i wpływu, a nie epistemologicznego uzasadnienia. Trafniejsze wydaje się sformułowanie, że podstawowa myśl pedagogiczna musi zachowywać teoretyczną ważność dla wszystkich subdyscyplin, niezależnie od tego, czy jest lokalnie - w danym historycznym środowisku - akurat znana i uznana, czy też nie. Zaślepienie, odmowa dialogu, tendencyjność, pominięcia wielkich dokonań etc. to zjawiska odnotowywane nader często przez socjologię nauki, a przecież nieunieważniające zasobów Popperowskiego trzeciego świata czy rezerwuaru istotnych, lecz nieobecnych w najbliższym otoczeniu wartości i idei - niewidzialnego środowiska, o którym pisała Helena Radlińska (por. Witkowski 2014). Wydaje się nawet, że zadanie pedagogów ogólnych polega właśnie na odpominaniu tych wątków dziedzictwa symbolicznego, które w bieżących i nazbyt zredukowanych ujęciach zostały zatarte ze szkodą dla rozumienia podstawowej struktury wychowania oraz na reinterpretowaniu tego, co rzeczywiście można i warto uznać za pedagogiczne (nie w sensie ustalania jakiegoś trwałego rdzenia problematyki pedagogicznej, lecz artykułowania tych kwestii, które uznajemy za wychowawczo istotne w każdorazowym zamachu koła hermeneutycznego). Obydwa dążenia - wydobywanie problemów z kulturowego letargu oraz powtarzanie pracy rozumienia - wchodzą w mniejszą lub większą kolizję ze stanem wiedzy, który jest aktualnie uznany w ramach poszczególnych dyscyplin oraz świadomości teoretyczno-metodologicznej ich reprezentantów. Oczywiście, istnieje możliwość, że normatywność warunku sformułowanego przez Bennera odnosi się do jakości recepcji wiedzy w środowiskach akademickich i chodzi autorowi po prostu o to, że podstawowa myśl pedagogiczna powinna zyskać uznanie 
w ramach subdyscyplin, którym nie wolno - pod groźbą degradacji teoretycznej - jej ignorować. Jeśli taki jest zamysł niemieckiego pedagoga, wypada się z nim zgodzić.

Nie można w każdym razie redukować pedagogiki ogólnej do badania części wspólnej i ustalania tez, które mogą zyskać aprobatę specjalistów różnych gałęzi nauk o wychowaniu w granicach gotowego horyzontu, w którym się oni poruszają. Nie może też być ujmowana jako formułowanie podstawowych zasad dla rzeczywistości z góry i niezmiennie identyfikowanej jako wychowawcza i to ani wtedy, gdy dzieje się to na mocy dogmatycznej dekretacji światopoglądowej, ani gdy stanowi odbicie aktualnej praktyki, która przecież może być - i często jest - powierzchowna i „uszkodzona” - pozbawiona kluczowych wymiarów i najcenniejszych odniesień kulturowych. Pedagogika ogólna to hermeneutyczne przedsięwzięcie przesuwania horyzontów w podejmowanej wciąż na nowo pracy polegającej na (re)interpretacji tego, co uznajemy za pedagogicznie istotne.

\section{Praca w tradycji}

Jeśli pedagogikę ogólną ująć jako perspektywę reinterpretacji podstawowej struktury wychowania pod kątem teoretycznej i praktycznej ważności, hierarchizacji poszczególnych elementów i funkcjonalności w systemie społecznym, jednym z jej podstawowych zadań staje się wprowadzanie myślenia pedagogicznego w newralgiczne debaty humanistyki. To z szerokiego pola autorefleksji kultury płyną impulsy pozwalające zobaczyć to, co pedagogiczne w nowych kontekstach, czyli w nowym teoretycznym świetle. Warunkiem możliwości dokonywania rewizji oraz resyntezy tego, co podstawowe w pedagogice, jest dostęp do najważniejszych dyskursów humanistyki. Pedagogika ogólna albo stanowi przedsięwzięcie transdyscyplinarne, ukierunkowane na przechwytywanie tropów z szeroko pojętej kultury, albo nie istnieje jako hermeneutyczna perspektywa.

Nauki humanistyczne - jak to znakomicie pokazuje Jerzy Szacki - polegają na inwencyjnym aktualizowaniu tradycji: „[...] oryginalność humanisty może paradoksalnie polegać na przypominaniu, na odczytywaniu raz jeszcze pochodzących z przeszłości znaków, na znajdowaniu sposobów obchodzenia się z tradycją, które, właśnie dzięki temu, że są nowe, przedłużają jej istnienie" (Szacki 1991, s. 109). Ten motyw znamy również - atoli tym razem $\mathrm{z}$ akcentem nie na nowość podejścia, lecz na obcość tkwiącą w transferze - z hermeneutyki Hansa-Georga Gadamera. Droga prawdy w naukach humanistycznych to wsłuchiwanie się w głosy tradycji - doświadczanie w historycznym przekazie impulsu, który nas wyprowadza poza samych siebie, a nie tylko takiego, który po prostu spełnia aktualne oczekiwania (por. Gadamer 2008, s. 106-107). Mamy zatem kolejne przybliżenie perspektywy organizacji badań, którą nazywamy pedagogiką ogólną. Skoro humanistyka to hermeneutyczna praca w tradycji (prze-pracowanie-przekazów-kulturowych), pedagogika ogólna staje się siłą rzeczy wprowadzeniem w rozmaite aktualizacje dziedzictwa symbolicznego pod kątem potencjalnych zysków dla rozumienia wychowania. Stąd tytuł niniejszego 
tekstu - pedagogika może być traktowana jako wprowadzenie do humanistyki, oczywiście bez żadnych „strukturalnych” skojarzeń propedeutycznych („wstęp do...”), tylko w sensie „perspektywicznego” lokowania czy wnoszenia problematyki wychowawczej praxis w ważne debaty nauk humanistycznych („wejście do...”).

Tak pojmowana pedagogika ogólna nie jest zasadniczo różna od historii wychowania, choć także nie jest z nią tożsama. Obie dyscypliny to w gruncie rzeczy dwa ustawienia tego samego hermeneutycznego pryzmatu - gdzie pierwsza na bazie tradycji formułuje podstawową myśl pedagogiczną dotyczącą podstawowej struktury wychowania (czyli usiłuje zrozumieć i zinterpretować to, co pedagogiczne), druga śledzi dziejowe odsłony idei, praktyk i instytucji, jakie się na ową pedagogiczność składają (próbuje zrozumieć i zinterpretować proces kształtowania się i zmienności problemów pedagogicznych). Perspektywy pedagogiki ogólnej i historii wychowania są dialektycznie powiązane (zwrotnie sprzężone) w myśl znanej maksymy, że teoria bez historii jest pusta, a historia bez teorii - ślepa. Jeśli większą uwagę przyłożymy do materiału dziejowego (bez zapominania o kategoriach, w których ten materiał ujmujemy), obieramy perspektywę historii wychowania; jeśli zaś nasza koncentracja ogniskuje się na teoretycznych kategoriach (bez zapominania o ich historycznych wariantach i uwikłaniach), przyjmujemy optykę pedagogiki ogólnej. To jedynie kwestia przesunięcia akcentów w organizacji badań, a nie separacji przedmiotu i kompetencji w społecznym podziale pracy. Usiłując uprawiać pedagogikę bez historii i historię wychowania bez zaawansowanego pedagogicznego zaplecza, skazujemy się albo na abstrakcyjną pustkę, albo na drobiazgowość bez znaczenia. Notabene, Łukasz Michalski pokazał niedawno w ważnym studium podręczników historyczno-pedagogicznych, w jaki sposób brak świadomości teoretycznej złożoności pojęć takich, jak wychowanie czy instytucja prowadzi do spłycenia perspektywy w historii wychowania i wtórnie ogranicza oddziaływanie tej dyscypliny na myślenie pedagogiczne. Dzieje się tak również wskutek braku przyswojenia sobie przez autorów dziejowych syntez krytycznego potencjału tzw. zwrotów w humanistyce (zwłaszcza lingwistycznego), co skutkuje niedocenieniem aktu narracji w procesie badawczym i atrofią warstwy refleksyjnej tekstu. Współczesne podręczniki historii wychowania, niedostatecznie wykorzystujące wiedzę pedagogiki ogólnej i innych dyscyplin, niemal pozbawione poziomu ironicznego (czyli metatekstowej świadomości konstruowania opowieści), właściwie się nie liczą - konstatuje Michalski - w sporze o tożsamość pedagogiki jako nauki (por. Michalski 2016). Tymczasem powinny one lokować się w awangardzie takiej debaty jako dysponujące pamięcią kulturową osiągnięć i pułapek dyscypliny. Nie trzeba dodawać, że te same argumenty krytyczne dotyczą również pedagogiki ogólnej, która nie dość wnikliwie operuje wiedzą z zakresu historii wychowania i nie pozostaje wystarczająco otwarta na wyzwania generowane przez tzw. cultural turns (por. Bachmann-Medick 2012; Kruszelnicki 2012; Witkowski 2013).

W grę - jak pokazuje także Bogdan Suchodolski w nawiązaniu do tekstów Wilhelma Diltheya i Ernsta Troeltscha - wchodzą tu nawet trzy elementy. 
Rozumienie historyczne (jak było) nie jest możliwe bez ujęcia przedmiotu systematycznie (co), i odwrotnie - systematyczna synteza nie jest możliwa bez materiału historycznego. Dochodzi do tego jeszcze kwestia założeń, jakie wnosi badacz z racji własnego uwikłania w czas, w którym żyje (przed-co, przed-jak-było). Na przykład zrozumienie historyczne myśli Immanuela Kanta udaje się tylko wtedy, gdy rozumiemy ją też rzeczowo, lecz aby tę myśl zrozumieć rzeczowo, potrzebujemy i odpowiedniej wiedzy historycznej, i założeń pochodzących ze współczesności (por. Suchodolski 1928, s. 14-16). A zatem ryzyko spłycenia perspektywy pedagogiki ogólnej leży nie tylko w jej separowaniu od historii wychowania jako odrębnego pola badawczego, lecz także w deficycie rozeznawania sytuacji hermeneutycznejhoryzontu, w którym się poruszamy (por. Gadamer 2004, s. 412-421).

\section{Między odrzuceniem a afirmacją tradycji}

W humanistycznej „obróbce” tradycji natrafiamy na dwa klasyczne uproszczenia, które nie są w stanie udźwignąć złożoności relacji teraźniejszości i skumulowanego kapitału kulturowego, i dlatego gdy stają się modus operandi w pedagogice, prowadzą do jej niekrytycznych, powierzchownych wersji.

Pierwsza redukcja polega na oświeceniowym geście odrzucenia tradycji jako autorytarnego balastu, od ciężaru którego trzeba się uwolnić w procesie wytwarzania wiedzy. Przekonanie - dziś już anachroniczne - że nauka wolna jest od odziedziczonego kapitału kulturowego, było silnie ugruntowane w racjonalizmie kartezjańskim (opartym na założeniu, że myślenie polega na odrzuceniu wszelkich mniemań zastanych i warunków wstępnych, zaciemniających światło rozumu) oraz w empiryzmie (ufundowanym na wyobrażeniu o uczonym, który buduje obraz świata z nagich faktów, nie dając się zwieść autorytetom) (por. Szacki 1991, s. 104-105). W niektórych wersjach racjonalizmu typu kartezjańskiego tradycja nie jest traktowana wyłącznie jako zbiór szkodliwych przesądów, ale także jako ciekawy materiał do testowania współczesnych rozwiązań i naszych zdolności krytycznych, wciąż jednak taki, do którego należy zachować pełny podmiotowy dystans. Takie stanowisko przyjmuje amerykańska intelektualistka, Martha Nussbaum, opowiadająca się za uchylaniem w edukacji autorytetu klasyków - prestiż wielkich ksiąg może usypiać czujność ucznia, odwodzić od samodzielnego poszukiwania, dlatego trzeba zniechęcić studiujących do oddawania tekstom jakiejkolwiek czci i do przyjmowania wobec lektury postawy biernej; książki to przedmioty przydatne w ćwiczeniach intelektualnych, nic więcej („,sztangi do trenowania umysłu”) (por. Nussbaum 2008, s. 44-46). Nussbaum uznaje za szczególnie istotną - a kształtowaną w ramach edukacji obywatelskiej - umiejętność argumentowania i prowadzenia dyskusji bez powoływania się na autorytet tradycji albo władzy; krytyczne podejście (w duchu sokratejskim) utożsamia z całkowitą wolnością od autorytetu; przygotowanie zaś do życia $\mathrm{w}$ demokracji widzi jako rezygnację $\mathrm{z}$ erudycji i smaku: „nie potrzeba już naszpikowanego mądrościami gromadzonymi przez 
wieki obytego gentlemana, ale aktywnego, krytycznego, myślącego i cechującego się empatią członka wspólnoty równych, zdolnego do wymieniania się ideami na zasadzie szacunku i zrozumienia dla ludzi wywodzących się z różnych środowisk" (Nussbaum 2016, s. 160).

Trzeba przyznać, że niemałe zdziwienie budzi fakt, iż tak uznana autorka, mająca skądinąd do powiedzenia wiele ciekawych rzeczy o wyobraźni literackiej czy kształceniu akademickim, aż tak płytko i naiwnie traktuje kwestię tradycji. Wszak zdolność czerpania głębokich inspiracji z dziedzictwa symbolicznego i umiejętność przyjmowania skupionej receptywnej postawy wobec źródeł (pełnego szacunku wsłuchiwania się w przekaz, który może przerastać ramy doświadczenia czytelnika) nie wyklucza ani krytycyzmu, ani empatii, a wręcz stanowi ich warunek jako dyspozycja czujności wobec własnego aktualnego horyzontu i jako otwartość na zasoby umożliwiające artykulację podmiotowych odniesień. Argumentacja odwołuje się do doświadczeń życia ludzkiego. Jeśli jej miarą uczynimy nie sensy i wartości biografii poszerzonej (o kapitał kulturowy), lecz doraźne przeżycia i punkty odniesienia, ryzykujemy zamknięcie w subiektywnej rzeczywistości, we własnym małym świecie, w którym ostatecznie nie damy sobie nic powiedzieć. Nussbaum - jak pokazał to Lech Witkowski, punktując autorkę za brak kompetencji hermeneutycznych - stereotypowo kojarzy autorytet wyłącznie z kontrolą i władzą, nie jest przeto zdolna do dostrzegania zniuansowanych sposobów obchodzenia się z tradycją, widząc wobec niej tylko dwie opcje: obronę albo atak. Bezpodstawne przypisywanie sobie racjonalności bez uprzedzeń daje w efekcie aroganckie zaślepienie w stosunku do innych niż analityczna tradycji myślowych oraz niezdolność do potraktowania spotkania z klasykami jako czegoś więcej niż tylko gimnastyki umysłowej (por. Witkowski 2011, s. 260-271).

Oświeceniowa idea unieważniania tradycji w imię autonomii rozumu - częściowo obecna też, na przykład, w okresie dorastania lub w obrębie ideologii w aktach nadidentyfikacji z jednym autorytetem kosztem wszystkich innych, a także w postawie aktywnej ignorancji charakterystycznej dla współczesnego cynizmu, w ramach którego jednostki nie obchodzi nic, co nie przynosi doraźnej korzyści, i co zakłóca dobrze zintegrowane ja - wpada w sidła braku wartościowych odniesień, w swego rodzaju mechanizm nicujący: „Zaskakuje ciągle wielu oczywista pułapka, że skoro każdy inny to jest nikt, kogo by warto potraktować na serio, posłuchać, przejąć się nim, to wpychamy się zarazem w przestrzeń, gdzie rządzą nic, nicość, unicestwienie, aż po wypierane ze świadomości poczucie, że samemu jest się owym "nic»" (Witkowski 2011, s. 25). Te wersje pedagogiki, które ignorują tradycje nauk o duchu (w tym własnych kluczowych debat), odwołując się jedynie do ateoretycznie projektowanych badań empirycznych albo do światopoglądowych inwariantów, a studiowanie mistrzów humanistyki oraz języków, które ci generują, mając za zbędny czy nawet szkodliwy balast, same zamykają się w granicach gotowego pola i skazują na teoretyczną degradację - jednostajność monologu, banalność wyników, niezdolność do reinterpretacji tego, co pedagogiczne. 
Drugim dysfunkcjonalnym dla operowania dziedzictwem kulturowym (a tym samym dla refleksji o wychowaniu) uproszczeniem jest afirmatywna repetycja. Jest faktem - co klarownie pokazał Jan Assmann - że podstawową zasadą konektywną, umożliwiającą istnienie pamięci kulturowej, stanowi powtórzenie. Dzięki niemu działanie ludzkie nie rozprasza się w nieskończenie wiele form, lecz przyjmuje postać rozpoznawalnych wzorców (por. Assmann 2008, s. 33). Jednak wiemy również - na przykład dzięki tartusko-moskiewskiej szkole semiotycznej czy hermeneutyce - że warunkiem owocnej komunikacji jest różnica potencjałów obu stron dialogu. Aby mogło dojść do Gadamerowskiej fuzji horyzontów, obcość przekazu musi być traktowana serio, z uwzględnieniem dziejowości, nie może ulec anihilacji w hegemonicznej intencji czytelnika. W radykalnej hermeneutyce Jacquesa Derridy rozumienie jest wręcz pojedynkiem - wystawianiem kontrsygnatury wobec nieoswajalnego głosu tego drugiego (por. Januszkiewicz 2012, s. 65-68). Oczywiście, generowanie nowego sensu w dialogu wymaga pewnej przestrzeni wspólnej - bez niej niemożliwy staje się przekład. Ale komunikacja zostaje zablokowana, jeżeli języki rozmówców się pokrywają. Dialog nie działa jak echo - aby był owocny, musi w nim dochodzić do zdarzeń, które Jurij Łotman nazwał nietrywialnym przesunięciem znaczenia - tłumacz cudzej mowy, nie znajdując gotowych odpowiedników, zmuszony jest do twórczego szukania ekwiwalentów (por. Żyłko 2009, s. 211-212).

W samym geście repetycji - skądinąd niezbędnym - czai się pułapka stłumienia ruchu myśli i etycznej wrażliwości przez gotowe, zastane, swojskie, oczywiste, nieprześwietlone treści i normy. Uczula na ten efekt Gabriel Marcel, wskazując, że wysiłek dokumentowania przeszłości jest potrzebny o tyle, o ile ożywia go wewnętrzne aksjologiczne nastawienie, o ile jego motor stanowi wdzięczność - rozumiana tu jako czujność i gotowość do osobistej odpowiedzi - wobec dziedzictwa. Istnieje aliści nieustanne ryzyko, że ten wysiłek zagłuszy nastawienie, które go usprawiedliwia: „[...] pojęcie duchowego dziedzictwa zostaje pozbawione treści w takiej mierze, w jakiej historia traci swoją żywotność, stając się po prostu gromadzeniem dokumentów, w jakiej «jest ona spisywaniem, nie zaś przypominaniem». Z takiej historii w rzeczywistości niepostrzeżenie znika wartość jako taka" (Marcel 2011, s. 55) ${ }^{1}$. I znów, te wersje pedagogiki, które w imię sentymentalnej idealizacji albo dokumentacyjnej skrupulatności powtarzają tezy poprzedników, stroniąc jednak od konfrontowania ich z rozległym dorobkiem humanistyki, degenerują się w monologi niezdolne do dokonywania nietrywialnych przesunięć znaczeń w polu tego, co pedagogiczne.

1 Tego mechanizmu w swojej obronie tradycji jako „świadomego powtórzenia” nie uwzględnia Paweł Grad (por. Grad 2017). 


\section{Pedagogika ogólna jako operowanie tradycją (zakończenie)}

Przedstawiłem tu w zarysie koncepcję pedagogiki ogólnej jako hermeneutycznego przedsięwzięcia, którego powodzenie zależy od pracy rozpoznawania horyzontu, w którym się badawczo poruszamy, czyli w praktyce od zdolności rozjaśniania własnych przed-założeń oraz sięgania do dawnych i współczesnych tekstów jako luster (lub, innymi słowy, zbiorników tez i przed-sądów), umożliwiających podjęcie realnego dialogu $\mathrm{z}$ tradycją - generowanie przemieszczeń semantycznych, a tym samym (re)interpretację i rewitalizację tego, co uznajemy za pedagogiczne.

Pedagogika ogólna będzie sprofilowana w ten sposób, o ile zachowa żywotną więź z historią wychowania i szerokim polem nauk humanistycznych, czyli o ile uniknie z jednej strony Scylli oświeceniowego gestu odrzucania tradycji (w tym autorytetu osiągnięć współczesnej humanistyki), a z drugiej - Charybdy zwykłej repetycji dziedzictwa, która w jednym akcie może przypominać jakąś treść i zarazem odbierać jej znaczenie. Jak pokazuje w przenikliwej uwadze Lech Witkowski, przejęcie materiału z zasobów tradycji nie oznacza koniecznie zdolności do jego reprodukowania, tylko przejęcie się jego wartością (Witkowski 2011, s. 481). Uprzywilejowaną strategią takiego przejmowania (się) i tym samym aktualizowania zasobów kultury jest to, co nazwałem kiedyś przechwytywaniem ciemnych iskier (Maliszewski 2013). Chodzi o wydobywanie z tradycji impulsów, które pozwalają nam rozeznać się w złożoności rzeczywistości - rozjaśniają ją na „ciemny” sposób, mądrze komplikują odniesienie do świata, uwzględniając warstwy, sploty, sprzężenia, imponderabilia. W hermeneutycznej pracy rozjaśniania horyzontu zyskujemy także świadomość wymykania się sensu, cienia obcości, spotkania z tym, czego nie sposób klarownie opowiedzieć. Pedagogika ogólna, która stanie się przedsięwzięciem przechwytywania ciemnych iskier tradycji, będzie pedagogiką teoretycznie i humanistycznie głębszą.

\section{Bibliografia}

Assmann J. (2008). Pamięć kulturowa. Pismo, zapamiętywanie i polityczna to $\dot{z}-$ samość w cywilizacjach starożytnych, tłum. A. Kryczyńska-Pham. Warszawa: Wydawnictwa Uniwersytetu Warszawskiego.

Bachmann-Medick D. (2012). Cultural Turns. Nowe kierunki w naukach o kulturze, tłum. K. Krzemieniowa. Warszawa: Oficyna Naukowa.

Benner D. (2015). Pedagogika ogólna. Wprowadzenie do myślenia i działania pedagogicznego w ujęciu systematycznym i historyczno-problemowym, tłum. D. Stępkowski. Warszawa: Wydawnictwo Uniwersytetu Kardynała Stefana Wyszyńskiego.

Gadamer H.-G. (2004). Prawda i metoda. Zarys hermeneutyki filozoficznej, tłum. B. Baran. Warszawa: PWN. 
Gadamer H.-G. (2008). Prawda w naukach humanistycznych. W: tenże. Teoria, etyka, edukacja. Eseje wybrane. Warszawa: Wydawnictwa Uniwersytetu Warszawskiego.

Grad P. (2017). O pojęciu tradycji. Studium krytyczne kultury pamięci. Warszawa: Fundacja Augusta Hrabiego Cieszkowskiego.

Januszkiewicz M. (2012). Kim jestem ja, kim jesteś ty? Etyka, tożsamość, rozumienie. Poznań: Wydawnictwo Poznańskie.

Kruszelnicki W. (2012). Zwrot refleksyjny w antropologii kulturowej. Wrocław: Wydawnictwo Naukowe Dolnośląskiej Szkoły Wyższej.

Maliszewski K. (2013). Ciemne iskry. Problem aktualizacji pedagogiki kultury. Toruń: Wydawnictwo Adam Marszałek.

Marcel G. (2011). Mądrość i poczucie sacrum, tłum. K. Chodacki, P. Chołda. Kraków: Arcana.

Markowski M. P. (2013). Polityka wrażliwości. Wprowadzenie do humanistyki. Kraków: Universitas.

Michalski Ł. (2016). Przemiany syntez niemożliwych. W stronę pedagogiczności podręcznikowej historiografii wychowania. Katowice: Wydawnictwo Uniwersytetu Śląskiego.

Mysłakowski Z. (1965). Wychowanie człowieka w zmiennej społeczności. Studia z filozofii wychowania. Warszawa: Książka i Wiedza.

Nussbaum M. C. (2016). Nie dla zysku. Dlaczego demokracja potrzebuje humanistów, tłum. Ł. Pawłowski. Warszawa: Biblioteka Kultury Liberalnej.

Nussbaum M. C. (2008). W trosce o człowieczeństwo. Klasyczna obrona reformy kształcenia ogólnego, tłum. A. Męczkowska. Wrocław: Wydawnictwo Naukowe Dolnośląskiej Szkoły Wyższej.

Suchodolski B. (1928). Przebudowa podstaw nauk humanistycznych. Warszawa: Ossolineum.

Szacki J. (1991). Tradycja i oryginalność w humanistyce. W: tenże. Dylematy historiografii idei oraz inne szkice $i$ studia. Warszawa: PWN.

Witkowski L. (2011). Historie autorytetu wobec kultury i edukacji. Kraków: Impuls.

Witkowski L. (2014). Niewidzialne środowisko. Pedagogika kompletna Heleny Radlińskiej jako krytyczna ekologia idei, umystu i wychowania. O miejscu pedagogiki w przełomie dwoistości w humanistyce. Kraków: Impuls.

Witkowski L. (2013). Przełom dwoistości w pedagogice polskiej. Historia, teoria, krytyka. Kraków: Impuls.

Żyłko B. (2009). Semiotyka kultury. Szkoła tartusko-moskiewska. Gdańsk: słowo/ obraz/terytoria. 


\title{
GENERAL PEDAGOGY AS AN INTRODUCTION TO THE HUMANITIES - HERMENEUTICS OF SYMBOLIC CAPITAL AND THE RECOVERY OF DARK SPARKS OF TRADITION
}

\begin{abstract}
General pedagogy as a place for the formulation of basic pedagogical thought is not a closed field with a specific subject, but a point of view that defines what is important in all subdisciplines of pedagogy and in educational practice. The task of such general pedagogy is to introduce the whole educational field into the crucial debates of the humanities - this means getting delivery of contexts to (re)define what is pedagogical. And since the humanities are largely a hermeneutic work over tradition, general pedagogy appears as a perspective of concern for the traditions of pedagogics. This text puts the issue of the general pedagogy in this way, trying to answer the question of what is and what is not a productive concern for tradition.
\end{abstract}

Key words: general pedagogy, history of education, humanities, tradition, hermeneutics, dark sparks.

Krzysztof Maliszewski - dr hab., kierownik Zakładu Podstaw Pedagogiki i Historii Wychowania w Instytucie Pedagogiki Uniwersytetu Śląskiego w Katowicach. Autor książek: Teoria wychowania moralnego w pedagogice kultury II Rzeczypospolitej (Katowice 2004); Ciemne iskry. Problem aktualizacji pedagogiki kultury (Toruń 2013); Pedagogika na pograniczu światów. Eseje z cyklu „Medium Mundi” (Katowice 2015); współredaktor ukazującej się w latach 2005-2016 serii wydawniczej pt. „Medium Mundi”. Redaktor części monograficznej czasopisma "Chowanna”, zatytułowanej: Niebezpieczna humanistyka - wywrotny wymiar pedagogiki i edukacji $(2017, \mathrm{t}$. 1). Jego zainteresowania naukowe koncentrują się na pedagogice filozoficznej (zwłaszcza aksjologicznych i antropologicznych aspektach wychowania), historii myśli pedagogicznej oraz problematyce pedagogiki kultury, a także na hermeneutycznych podstawach humanistyki. Adres do korespondencji: Wydział Pedagogiki i Psychologii UŚ, ul. Grażyńskiego 53, 40-126 Katowice. Adres e-mailowy: krzysztof.maliszewski@us.edu.pl. 